\title{
Mobile phone banking: A comparative analysis of e-service quality and customer loyalty of banking applications and Unstructured Supplementary Service Data services
}

\begin{tabular}{|c|c|}
\hline \multicolumn{2}{|c|}{$\begin{array}{l}\text { Authors: } \\
\text { Darlington Chigor } \\
\text { Kim Viljoen } 1 \text { (1) } \\
\text { Mari Ford }{ }^{1} \\
\text { Liezel Cilliers }^{2}\end{array}$} \\
\hline \multicolumn{2}{|c|}{$\begin{array}{l}\text { Management and Commerce, } \\
\text { University of Fort Hare, } \\
\text { East London, South Africa }\end{array}$} \\
\hline \multicolumn{2}{|c|}{$\begin{array}{l}{ }^{2} \text { Department of Information } \\
\text { Systems, Faculty of } \\
\text { Management and Commerce, } \\
\text { University of Fort Hare, } \\
\text { East London, South Africa }\end{array}$} \\
\hline \multicolumn{2}{|c|}{$\begin{array}{l}\text { Corresponding autho } \\
\text { Kim Viljoen, } \\
\text { kviljoen@ufh.ac.za }\end{array}$} \\
\hline \multicolumn{2}{|c|}{$\begin{array}{l}\text { Received: } 29 \text { Mar. } 2019 \\
\text { Accepted: } 25 \text { Nov. } 2019 \\
\text { Published: } 20 \text { July } 2020\end{array}$} \\
\hline \multicolumn{2}{|c|}{$\begin{array}{l}\text { How to cite this article: } \\
\text { Chigori, D., Viljoen, K., } \\
\text { Ford, M. \& Cilliers, L., 2020, } \\
\text { 'Mobile phone banking: A } \\
\text { comparative analysis of } \\
\text { e-service quality and } \\
\text { customer loyalty of banking } \\
\text { applications and } \\
\text { Unstructured Supplementary } \\
\text { Service Data services', Journal } \\
\text { of Economic and Financial } \\
\text { Sciences 13(1), a471. https:// } \\
\text { doi.org/10.4102/jef.v13i1.471 }\end{array}$} \\
\hline \multicolumn{2}{|c|}{$\begin{array}{l}\text { Copyright: } \\
\text { (c) 2020. The Authors } \\
\text { Licensee: AOSIS. This } \\
\text { is licensed under the } \\
\text { Creative Commons } \\
\text { Attribution License. }\end{array}$} \\
\hline \multicolumn{2}{|l|}{ Read online: } \\
\hline 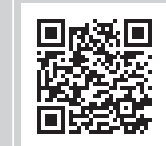 & $\begin{array}{l}\text { Scan this QR } \\
\text { code with your } \\
\text { smart phone or } \\
\text { mobile device } \\
\text { to read online. }\end{array}$ \\
\hline
\end{tabular}

Orientation: Mobile devices are becoming a popular means to access the Internet and conduct e-banking activities. Banks are marketing e-banking solutions to increase their customer base.

Research purpose: This study contrasts how the service quality of mobile phone applications and Unstructured Supplementary Service Data banking influence customer loyalty. The study examined e-service quality to validate and determine the nature of the relationship of the proposed model.

Motivation for the study: The study was conducted in a mobile banking (MB) setting in South Africa, with a technologically savvy young adult population. To win customer loyalty, banks need to provide innovative solutions to this group of clients.

Research approach/design and method: A positivistic paradigm with a quantitative approach and descriptive design was adopted for this study. A convenience sampling method was used to distribute a questionnaire to 300 students, with a response rate of $73 \%$.

Main findings: The findings showed that fulfilment, privacy and efficiency were all significantly related to overall service quality and customer loyalty for both banking models. Based on the findings, privacy, fulfilment and efficiency are critical facets to both MB applications and Unstructured Supplementary Service Data banking.

Practical/managerial implications: Banks need to target 'unbanked' customers to register for a bank account via Unstructured Supplementary Service Data banking or MB applications.

Contribution/value-add: However, there is still a lack of knowledge about these services among the population. Therefore, banks need to educate potential and existing customers on these products and services to fully exploit the market segments.

Keywords: mobile banking service quality; mobile banking applications; mobile banking USSD services.

\section{Introduction}

Technology is continually changing the way products and services are being delivered from one industry to the other (Hodgkinson 2015). In the banking sector, the need to transform from traditional banking methods (automated teller machine [ATMs], Internet banking and bank tellers) to mobile banking (MB) (telephone banking, banking applications and Unstructured Supplementary Service Data [USSD] banking) has been driven by innovation as well as customer need (Singh 2012). Mobile banking has made banking services more efficient and effective, as it increases the convenience and proximity of the services to the customer. Mobile banking has even enabled customers to travel anywhere across the globe with the bank in their 'pocket' (Honigman 2014).

The mobile phone banking sector in South Africa is still relatively new, which means that consumers may have service quality (SQ) concerns, which may lead to them not adopting this type of banking (Shanka 2012). In South Africa, the banking sector is very competitive, which means that mobile banking service quality (MB SQ) is critical to the optimisation of service delivery and achievement of customer loyalty and satisfaction (Burger 2010). In fact, many banks are using $\mathrm{MB}$ in their marketing campaigns to distinguish themselves from the competition. Thus, MB services have increased the competitiveness of banking services in the industry. While MB has 
become an accepted part of the banking industry, the focus has now moved on to $\mathrm{SQ}$, which has now become a deciding factor for customers when they decide where to bank. Customer perceptions of the SQ in mobile phone banking also have implications for customers' long-term loyalty (Halliburton \& Poenaru 2010; Shanka 2012).

\section{Literature review}

\section{Background}

Services are defined as a series of activities of an intangible nature, which are necessarily valuable action, deed or effort performed to satisfy a need or fulfil a demand (Grönroos 2001). The dominance of the service sector has been witnessed in most industrialised countries. This sector has shown a considerable contribution to economic development. More importantly, the service sector offers opportunities to stay competitive to both businesses and entrepreneurs in South Africa (Lovelock \& Wirtz 2011). In South Africa, the services sector, which contributes approximately $70 \%$, is a major contributor to the national revenue (Boshoff 2014). The banking and financial sector, with other service sectors, is a pillar of the country's economic growth, enhancing growth in many domestic businesses (Boshoff 2014; Lovelock \& Wirtz 2011). South Africa's banking sector compares favourably with those of industrialised countries (BASA 2014).

Innovation in technology in the service sector has mostly been applied to decrease costs (Erspective \& Lusch 2015). Many sectors, especially the banking sector, use technology to regulate services by minimising the employee or customer interface which, in turn, is more cost-effective. A great number of customers are opting for technology-based service delivery systems (Lu, Geng \& Wang 2015). Technology provides an opportunity for banks and financial institutions to support the economic growth of South Africa (Dobush 2015; Fenu \& Pau 2015; Shaikh \& Karjaluoto 2014). Mobile banking services are freely available on the Internet and overcome some of the difficulties that limit traditional banking services (Parasuraman, Zeithaml \& Berry 1985; Singh 2012). Recently, banking has evolved to include communication channels such as telephone banking and online banking. However, not all customers have access to these services, as they cannot afford expensive telephone calls or data.

\section{Unstructured Supplementary Service Data banking}

Short message services (SMS) banking has been immensely popular with the majority of South Africans since its launch (Matthew 2013). Recently, SMS banking has been overtaken by USSD banking, which was initially designed to target potential customers in rural areas (Ivatury \& Pickens 2006; Masocha, Chiliya \& Zindiye 2011). The banking sector hoped to reach unbanked customers in rural areas, as USSD banking makes it easy to access banking services. Unstructured Supplementary Service Data services can be used by customers who possess any mobile phone with or without a General Packet Radio System (GPRS) connection (Shaikh \& Karjaluoto
2014). Unstructured Supplementary Service Data services make use of real-time transactions and are free, although some charges from the mobile network provider may be applicable. Customers dial a specific code to transact with the bank (which differ from bank to bank). However, individuals have to register their mobile numbers with the bank to access this service (Matthew 2013). The most common services offered through USSD banking include viewing balances, buying prepaid airtime, paying electricity charges, SMS and data bundles, sending money, paying accounts, applying for loans, making payments (including once-off payments), transferring money between accounts and placing notices on savings accounts (Nyeko et al. 2014).

\section{Mobile banking applications}

Mobile banking, which is also sometimes referred to as MB apps by the general public, 'is a service which allows you to access your bank account details and transact over the internet through a mobile banking application' (Axis Bank 2016:1). The service is accessible through mobile data services ( $2 \mathrm{G}, 3 \mathrm{G}, 4 \mathrm{G}$ or even $5 \mathrm{G}$ in specific regions) or Wi-Fi. Mobile banking apps are optimised for iOS, Android and Blackberry phones (Matthew 2013) and can also be used on Java or nonJava mobile phone handsets using the GPRS network connection. Mobile banking apps can be downloaded from a bank's website, Google Play Store or Apple iStore.

Mobile banking apps provide the majority of banking services provided by the bank on individuals' phones and give customers the freedom to carry out most banking activities in the privacy of their homes (Axis Bank 2016; Matthew 2013). The most commonly available services offered through MB apps include: access to bank accounts, account statements and transaction history, transfer money to various accounts as well as different banks worldwide, pay accounts and bills such as water and electricity, request cheque books and stop order payments, as well as contact and location information of branches and ATMs. Notably, in South Africa, services offered through MB apps differ from one bank to another.

Technology is providing banking and financial institutions with different methods of improving SQ and building customer loyalty to obtain or maintain a competitive advantage (Oppong, Adjei \& Poku 2014). Although it is implicit that mobile phone banking is making an enormous contribution on the South African economy, banks in South Africa are still in the infancy stages with regard to this technology (Hodgkinson 2015; Ondiege 2010; EffectiveMeasure 2014). Banks and financial institutions have so far been able to establish websites and design applications to accommodate different customers' needs, but research on how to harness MB and USSD services has been sparse. Thus far, only a few scholars have considered the importance of SMS and USSD in the banking industry, and even fewer have focussed on MB applications and USSD banking concerning perceptions of SQ and its impact on customer loyalty (Adewoye2013; Duff 2014; EffectiveMeasure 
2014; Matthew 2013; Van Velden et al. 2015). According to Hanafizadeh et al. (2014), the usage of mobile phones in banking is believed to reinforce the bond between financial services providers and customers. This study therefore sought to compare how the SQ of USSD services and MB apps impacts on customer loyalty in the South African banking context.

\section{Theoretical literature E-S-QUAL}

The SQ framework SERVQUAL was developed to evaluate the consumption experiences in traditional non-Internetbased and non-electronic products but was found not to be suitable for electronic services (e-services). It can be noted that e-services differ from traditional services in that customers relate to the company through an electronic site or application (Parasuraman, Zeithaml \& Malhotra 2005; Wahab et al. 2011). The four dimensions of electronic service quality (E-S-QUAL) have been applied to numerous studies over the years (Ayo et al. 2016; Kim \& Nitecki 2014; Parasuraman et al. 2005; Rafiq, Lu \& Fulford 2012; Paschaloudis \& Tsourela 2014; Zehir et al. 2014).

Fulfilment is the degree to which the site guarantees completion of order or transaction. This dimension is sometimes referred to as 'reliability' in other studies (Kim, Jin \& Swinney 2009; Kim, Kim \& Lennon 2006; Parasuraman et al. 2005). According to Parasuraman et al. (2005), fulfilment refers to the degree to which the site's assurances about commands or directives provision and item accessibility fulfil the customer's need for banking services. This construct encompasses precise commands and product representation.

Efficiency is defined as the simplicity and speed of getting into and using the service (Parasuraman et al. 2005). It is considered significant in e-commerce because time-saving and accessibility are key reasons for using e-services (Kim et al. 2006; Wahab et al. 2011).

Privacy is the extent to which the site guarantees to safeguard and protect customer information. Customers are reluctant to purchase products and make transactions from both the Internet and their electronic devices owing to the risks associated with the use of technology and misuse of customers' information (Santouridis \& Kyritsi 2014). Wahab et al. (2011) found that privacy has a strong effect on customer loyalty on cell phone usage.

System availability relates to the accurate technical functioning of the site (Parasuraman et al. 2005; Wahab et al. 2011). When consumers are online or browsing the site, problems relating to functioning, like missing links or broken buttons, will increase the likelihood of customers leaving the site (Wahab et al. 2011), and decrease customer loyalty.

Customer satisfaction has always been reflected as grounded in the customer's prior experiences of service encounters (Agbor
2011). Customer satisfaction measures how products or services supplied by a company meet or surpass a customer's expectation (Beard 2014). It is the greatest indicator of potential customer purchases which leads to customer loyalty. In a highly competitive market, customer satisfaction is seen as a critical success factor. Agbor (2011) suggested that SQ is one of the possible dimensions that can be used in measuring customer satisfaction. Different aspects affect customer satisfaction. Recent studies show that perceived SQ is an element of customer satisfaction. This concept acts in accordance with the conception of Zeithaml, Bitner and Gremler (2013) and has been confirmed by the definition of customer satisfaction offered by other scholars. The link between customer satisfaction and SQ encourages repeat purchases which have aided customer loyalty and has been known to apply to most service industries. Studies in banking have also indicated that SQ, loyalty and customer satisfaction are interrelated (Ariff et al. 2013; Shanka 2012). As a relationship exists between SQ and customer satisfaction, as well as customer loyalty (Ariff et al. 2013), knowledge of the E-S-QUAL relationship between perceived overall quality and customer loyalty in the current study will also contribute to features of E-S-QUAL in MB that lead to customer satisfaction.

In this study, relationships are proposed between selected e-SQ dimensions (efficiency, fulfilment, privacy and systems availability) and their influence on overall SQ as well as their contribution towards customer loyalty. The first conceptual model focusses on USSD banking and related SQ, while the second model focusses on $\mathrm{MB}$ apps and their related SQ dimensions. The presentation of hypotheses and the 10 propositions for the study were tested through partial least squares structural equation modelling (PLS-SEM). The following section presents the hypotheses related to the two conceptual models.

Model 1: Unstructured Supplementary Service Data banking service quality hypotheses

$\mathbf{H}^{\text {aa: }}$ The efficiency of USSD banking has a significantly positive influence on the overall SQ of USSD banking.

$\mathbf{H}^{2 a}$ : The fulfilment of USSD banking has a significantly positive influence on SQ of USSD banking.

$\mathbf{H}^{3 a}$ : Privacy of USSD banking has a significantly positive influence on SQ of USSD banking.

$\mathbf{H}^{\text {aa }}$ : System availability of USSD banking has a significantly positive influence on SQ of USSD banking.

$\mathbf{H}^{5 a}$ : Perceived overall e-SQ of USSD banking has a significantly positive influence on customer loyalty.

Model 2: Mobile banking apps banking service quality hypotheses

$\mathbf{H}^{\mathrm{ib}}$ : The efficiency of mobile phone banking applications has a significantly positive influence on the overall SQ of mobile phone banking apps.

$\mathbf{H}^{2 b}$ : The fulfilment of mobile phone banking applications has a significantly positive influence on SQ of mobile phone banking apps. 
$\mathbf{H}^{3 \mathbf{b}}$ : Privacy of mobile phone banking applications has a significantly positive influence on SQ of mobile phone banking apps.

$\mathbf{H}^{\mathrm{4b}}$ : System availability of mobile phone banking applications has a significantly positive influence on SQ of mobile phone banking apps.

$\mathbf{H}^{5 \mathbf{b}}$ : Perceived overall e-SQ of mobile phone banking applications has a significantly positive influence on customer loyalty.

The study examined e-SQ in terms of efficiency, fulfilment, privacy and systems availability to validate and determine the nature of the relationship of the proposed models that were provided in the section above for USSD banking and MB applications, respectively.

\section{Research methodology and design}

University students are technology savvy and use mobile phones more than other age groups, and were thus deemed an appropriate population (Singh 2012). A total of 300 selfadministered questionnaires were distributed to a convenience sample of university students of which 218 (73\%) were returned. Participation in the survey was assessed by qualifying criterion, which consisted of whether respondents had a bank account and made use of either USSD banking and/or MB apps in the past. To ensure that ethical standards were followed, ethical clearance was obtained from the necessary governing body. Different empirical studies were analysed to extract foundational meanings for key constructs such as SQ, e-SQ and customer loyalty. This survey questionnaire was adapted and modified from Kim (2015), Aldas-Manzano et al. (2011), Parasuraman et al. (2005), Yang and Tsai (2007) and Zeithaml, Berry, and Parasuraman (1996). The selection of suitable variables and constructs to represent both SQ and customer loyalty were subject to careful analysis of previous studies' reliability and validity statistical values. The researcher adopted a causal comparative and descriptive research design to disclose the effect of e-SQ on the enhancement of customer loyalty on two different modes of MB.

\section{Discussion of findings Demographic results}

The majority of respondents in this study were female students ( $n=137 ; 62.8 \%$ ), while male students made up $37.2 \%$ of the sample. Most respondents (78\%) were between the ages of 18 and 25 years, which is appropriate for this sample. A detailed breakdown of the respondents' ages is shown in Figure 1.

With regard to the choice of banks, Figure 2 shows that the majority of students, 99 (45.4\%), banked with Capitec Bank, followed by 50 (22.9\%) students with First National Bank, 34 students (15.6\%) with Standard Bank, 19 students (8.7\%) with Amalgamated Banks of South Africa (ABSA), and the least number of students,15 (6.9\%) banked with Nedbank.

The mode of MB used by students revealed that 100 (45.9\%) students used both MB app and USSD banking. Students using

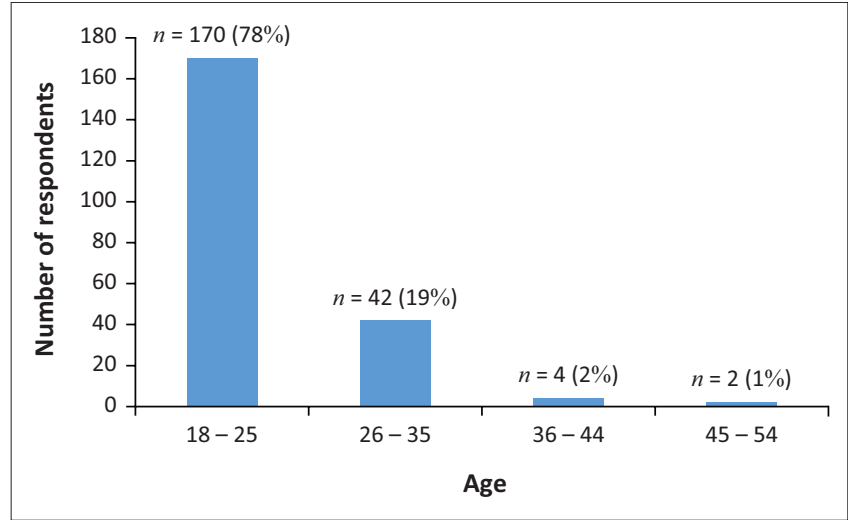

FIGURE 1: Age of respondents.

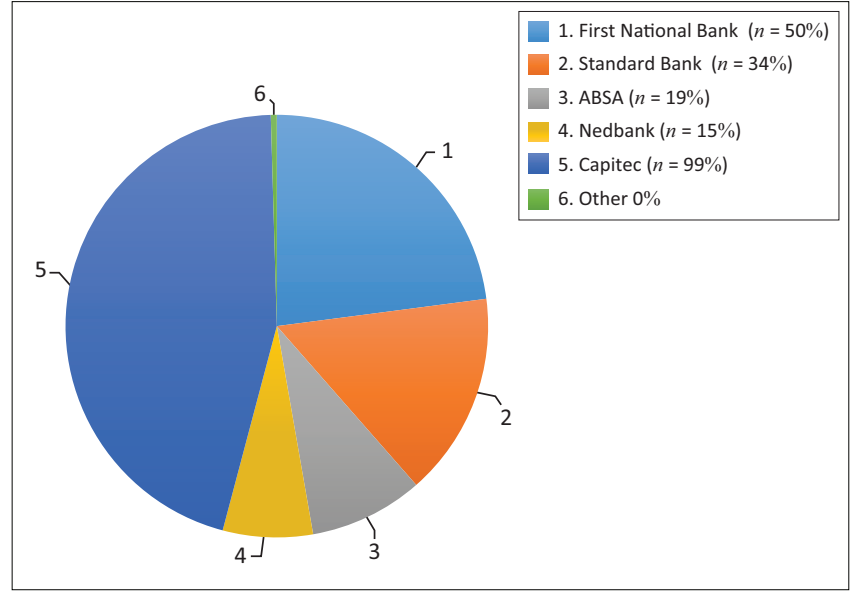

FIGURE 2: Choice of bank.

just USSD banking were the next biggest group $(n=77 ; 35.3 \%)$, followed by students using just the MB app ( $n=41 ; 18.8 \%)$, which is the smallest group. Figure 3 shows that fewer students prefer the MB app, compared to USSD banking (35.3\% > $18.8 \%$ ). It is not clear why more students prefer to use both modes of banking rather than either USSD banking or MB app, but this may have something to do with the fact that they are both now readily available on a smartphone. Interestingly, some of the respondents did not know that the banking services they were using are called USSD banking or MB apps. Therefore, banks need to educate their customers on their products and services to fully exploit their market segments.

\section{Reliability and validity of constructs}

Table 1 presents the range of factor loadings for $\mathrm{MB}$ app and Cronbach's alpha coefficients for E-S-QUAL, overall SQ and customer loyalty. The constructs were slightly modified and adapted to suit the current study. The Cronbach's alpha coefficients ranged from 0.781 to 0.854 for the E-S-QUAL scale, thus exceeding the critical values proposed by Parasuraman et al. (2005) (0.7) and confirming high internal dimension stability for the scales. The factor loadings were above critical values and deemed valid. The customer loyalty scale also indicated a high range of factor loadings (0.694-0.866) and an alpha coefficient of 0.872 , which confirmed internal validity. In addition to the above, overall quality also showed a high coefficient alpha of 0.784 as 
well as an acceptable range of confirmatory factor analysis (CFA) ranging from 0.565 to 0.807 .

The discussion and presentation of results on the validity and reliability of USSD banking follow below. The data analysis results in Table 2 were all above the minimum critical values for both the CFA and Cronbach's alpha coefficients. The lowest CFA values for the constructs were 0.414 , while the highest value was 0.967 . Similarly, the Cronbach's alpha coefficients for USSD banking were well above the critical value of 0.7 . Therefore, the results presented in Table 2 all showed that the values were all above the minimum required values and were thus considered reliable and valid.

In line with exploratory factor analysis (EFA) results presented by Kim (2015) on fulfilment, the fulfilment scale (USF) displayed uni-dimensionality of the construct with similar loadings to the one on USF. The results presented by Kim (2015) had lower loadings ranging between 0.50 and 0.63 . However, the results presented in this study showed higher loadings ranging between 0.610 and 0.888 on the first factor and 0.414 and 0.967 on the second factor. Considering the overall values of alpha coefficients, USSD banking had a higher Cronbach's coefficient, compared to MB app values.

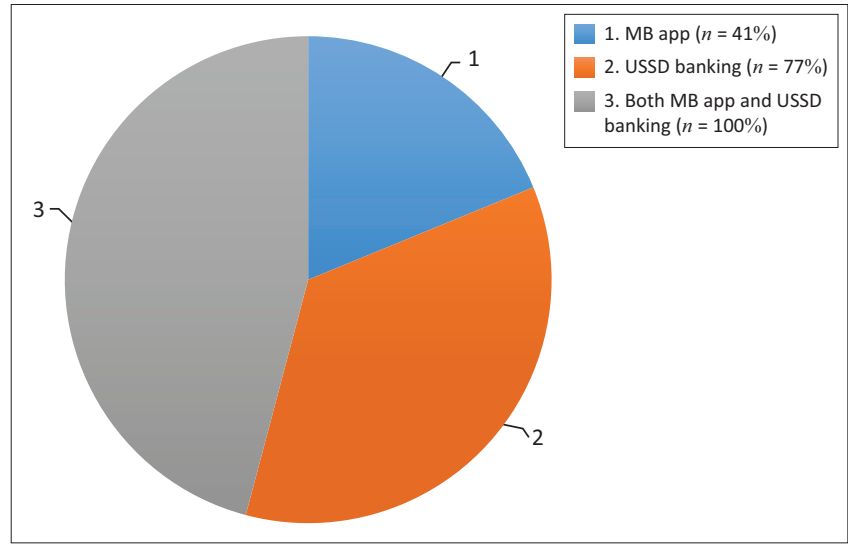

FIGURE 3: Mode of mobile banking.

TABLE 1: Validity and reliability of a mobile banking app.

\begin{tabular}{lccc}
\hline Constructs & No. of items & $\begin{array}{c}\text { Range of factor } \\
\text { loadings }\end{array}$ & $\begin{array}{c}\text { Cronbach's } \\
\text { alpha } \\
\text { coefficients }\end{array}$ \\
\hline Systems availability (MBSA) & 4 & $0.565-0.807$ & 0.781 \\
Overall service quality (MBQ) & 4 & $0.577-0.777$ & 0.784 \\
Privacy (MBP) & 3 & $0.650-0.915$ & 0.808 \\
Efficiency (MBE) & 8 & $0.512-0.745$ & 0.820 \\
Fulfilment (MBF) & 7 & $0.552-0.789$ & 0.854 \\
Customer loyalty (MBL) & 5 & $0.694-0.866$ & 0.872 \\
\hline
\end{tabular}

TABLE 2: Summary of reliability Unstructured Supplementary Service Data banking.

\begin{tabular}{lccc}
\hline Constructs & No. of items & Range of loadings & Cronbach's alpha \\
\hline Systems availability (USSA) & 4 & $0.593-0.852$ & 0.806 \\
Fulfilment (USF) & 7 & $0.414-0.967$ & 0.837 \\
Privacy (USP) & 3 & $0.814-0.929$ & 0.837 \\
Overall service quality (USQ) & 4 & $0.693-0.806$ & 0.839 \\
Efficiency (USE) & 7 & $0.532-0.773$ & 0.844 \\
Customer loyalty (USL) & 5 & $0.729-0.858$ & 0.884 \\
\hline
\end{tabular}

In the same manner, the CFA values of USSD banking were also higher.

\section{Goodness-of-fit indices for measurement and structural model}

Although the goodness-of-fit for PLS-SEM has been suggested, research has shown that it is not suitable for poorly designed models (Henseler \& Sarstedt 2013). As a result, the PLS-SEM has exclusively been utilised to show a model's predictive capability to evaluate the model's quality (Henseler, Ringle \& Sarstedt 2014). Henseler and Sarstedt (2013) explained in detail that the global goodness-of-fit for PLS-SEM by Tenenhaus, Amato and Vinzi (2014) did not represent a fit measure and should not be considered for goodness-of-fit tests.

\section{Pearson correlations, multiple regression and structural path analysis}

\section{Pearson correlation analysis results of Unstructured Supplementary Service Data banking and mobile banking apps}

The Pearson correlation analyses revealed that the USSD had a stronger influence on both customer retention as well as SQ. The findings in Table 3 show that the correlation of customer loyalty (TUSL) and overall SQ (TUSQ) for USSD banking were marginally higher (0.589) than that of $\mathrm{MB}$ app (0.501). Similarly, the correlation coefficient of fulfilment (TUSF) and overall SQ (TUSQ) for USSD banking was more significant than the relationship of fulfilment (MBF) and overall SQ (MBQ) of MB app (0.645 > 0.552).

TABLE 3a: Pearson correlation coefficient results of Unstructured Supplementary Service Data banking.

\begin{tabular}{lcccccc}
\hline Constructs & TUSQ & TUSL & TUSF & TUSE & TUSSA & TUSQ \\
\hline USSD banking & & & & & & \\
$\begin{array}{l}\text { Overall service } \\
\text { quality (TUSQ) }\end{array}$ & 1.000 & - & - & - & - & - \\
$\begin{array}{l}\text { Customer loyalty } \\
\text { (TUSL) }\end{array}$ & 0.589 & 1.000 & - & - & - & - \\
Fulfilment (TUSF) & 0.645 & 0.654 & 1.000 & - & - & - \\
& $(0.000)$ & $(0.000)$ & & & & \\
Efficiency (TUSE) & 0.637 & 0.646 & 0.752 & 1.000 & - & - \\
& $(0.000)$ & $(0.000)$ & $(0.000)$ & & & \\
Systems availability & 0.520 & 0.348 & 0.567 & 0.587 & 1.000 & - \\
(TUSSA) & $(0.000)$ & $(0.000)$ & $(0.000)$ & $(0.000)$ & & \\
Privacy (TUSP) & 0.537 & 0.399 & 0.446 & 0.493 & 0.412 & 1.000 \\
& $(0.000)$ & $(0.000)$ & $(0.000)$ & $(0.000)$ & $(0.000)$ & \\
\hline & & & & & & \\
& & & & & & \\
& & & & & & \\
& & & & & &
\end{tabular}

TABLE 3b: Pearson correlation coefficient results of Unstructured Supplementary Service Data banking.

\begin{tabular}{lcccccc}
\hline Constructs & TMBQ & TMBL & TMBF & TMBE & TMBSSA & TMBP \\
\hline Mobile banking application & & & & & \\
$\begin{array}{l}\text { Overall service } \\
\text { quality (TMBQ) }\end{array}$ & 1.000 & - & - & - & - & - \\
$\begin{array}{l}\text { Customer loyalty } \\
\text { (TMBL) }\end{array}$ & 501 & 1.000 & - & - & - & - \\
Fulfilment (TMBF) & $(0.000)$ & & & & & \\
& $(0.55$ & 0.644 & 1.000 & - & - & - \\
Efficiency (TMBE) & 0.632 & 0.555 & 0.612 & 1.000 & - & - \\
& $(0.000)$ & $(0.000)$ & $(0.000)$ & & & \\
Systems availability & 0.485 & 0.198 & 0.448 & 0.490 & 1.000 & - \\
(TMBSA) & $(0.000)$ & $(0.009)$ & $(0.000)$ & $(0.000)$ & & \\
Privacy (TMBP) & 0.655 & 0.396 & 0.434 & 0.562 & 0.440 & 1.000 \\
& $(0.000)$ & $(0.000)$ & $(0.000)$ & $(0.000)$ & $(0.000)$ & \\
\hline
\end{tabular}


The same trend of interrelation was also depicted on efficiency (TUSE) and overall SQ (TUSQ). However, although efficiency (TUSE) and overall SQ (TUSQ) had a higher correlation (0.637), the difference was minimal in comparison to the correlation between efficiency (MBE) and overall SQ (MBQ) (0.632). Systems availability (TUSSA) and overall SQ (TUSQ) also showed that a higher correlation of 0.520 , compared to 0.485 exhibited between systems availability (MBSA) and overall SQ (MBQ). Although most of the USSD banking constructs indicated higher SQ levels, the privacy of $\mathrm{MB}$ app solely indicated that it is more significant on the MB application SQ (0.655) than it is for USSD banking (0.537).

\section{Multiple regressions analysis of Unstructured Supplementary Service Data banking and mobile banking apps}

The data for the conceptual MB app model show an adjusted $R^{2}=0.559$. This points towards $55.9 \%$ total variability in overall SQ illuminated by customer loyalty (USL), fulfilment (USF), efficiency (USE) and systems availability (USSA). Moreover, the adjusted $R^{2}$ of $55.9 \%$ is a moderate model predictability. $F$-statistics $(F=36.599)$ indicates that the model has explanatory power, which means that the coefficients are above zero. This means that the model is significant as it has explanatory power of independent variables on dependent variables $(p=0.000)$. Table 5 shows that privacy (MBP), systems availability (MBSA) and efficiency (MBE) contribute significantly to the prediction of overall SQ (MBQ) except fulfilment (MBF) and customer loyalty (MBL).

The findings of the regression in Table 4 indicate that the model for the MB app has a higher prediction capacity, compared to the model for USSD banking. The findings also revealed diverse results. The regression on the model of USSD banking displayed that customer loyalty (USL) is a predictor

TABLE 4: Multiple regression analysis model summary for Unstructured Supplementary Service Data (USSD) banking and mobile banking app.

\begin{tabular}{lccc}
\hline Constructs & $\boldsymbol{B}$ & Std. error of $\boldsymbol{\beta}$ & $\boldsymbol{p}$ \\
\hline \multicolumn{2}{l}{ Regression analysis model summary for USSD banking } & & \\
Overall service quality (USQ) & - & - & 0.031 \\
Customer loyalty (USL) & 0.221 & 0.052 & 0.003 \\
Fulfilment (USF) & 0.214 & 0.051 & 0.014 \\
Efficiency (USE) & 0.133 & 0.052 & 0.130 \\
Systems availability (USSA) & 0.151 & 0.055 & 0.024 \\
Privacy (USP) & 0.226 & 0.070 & 0.000 \\
Regression analysis model summary for MB app & & \\
Customer loyalty (MBL) & - & - & 0.113 \\
Fulfilment (MBF) & 0.138 & 0.053 & 0.082 \\
Efficiency (MBE) & 0.109 & 0.046 & 0.195 \\
Systems availability (MBSA) & 0.210 & 0.046 & 0.012 \\
Privacy (MBP) & 0.141 & 0.058 & 0.044 \\
Overall service quality (MBQ) & 0.373 & 0.078 & 0.000 \\
\hline
\end{tabular}

Note: Regression analysis model summary for USSD banking $R=0.553 ; R^{2}=0.540$; $F=42.316 ; p=0.000$, Std. error of estimate: 1.873 ; Regression analysis model summary for $\mathrm{MB}$ app $R=0.575 ; R^{2}=0.559 ; F=36.599 ; p=0.000 ;$ Std. error of estimate: 1.709 of overall SQ (USQ). The regression of the MB app showed contradicting results. It showed that customer loyalty (MBL) of the MB app is not significant. These findings show varied results that could be because of different factors. The findings could be because USSD banking does not require one to be connected to the Internet to use it, whereas MB app requires connection to the Internet. Therefore, loyalty to USSD could be linked to the lower costs to use it, leading to repeat customers. The next section comprises the discussion of the structural path models.

\section{Structural path analysis}

\section{Model for Unstructured Supplementary Service Data banking}

The PLS-SEM path model displayed in Figure 4 for USSD banking proved four positively significant relationships. The path analysis results concerning USSD efficiency and USSD overall SQ $(t=2.289)$ proved higher than 1.96 and are therefore considered significant. With respect to the relationship between USSD fulfilment and USSD overall SQ, a positively significant relationship value of 3.231 was reported. The USSD overall SQ and USSD customer loyalty exhibited a stronger significantly positive $t$-statistics of $t=7.763$. Unstructured Supplementary Service Data privacy also displayed a significantly positive relationship with overall SQ. This was established through a $t$-statistical value of 2.600. Although all the other variables were significant, USSD systems availability and USSD overall SQ were statistically not significant $(t=1.387)$ because the $t$-value was below the minimum required critical value of 1.960 . The model shown in Figure 4 therefore summarises the relationships discussed above and their causal effect on E-S-QUAL and customer loyalty.

TABLE 5: Multicollinearity variance inflation factor path coefficients.

\begin{tabular}{lcc}
\hline Variables & VIF value range & Path coefficient \\
\hline Efficiency $\longrightarrow$ E-s-quality & $1-5$ & $0.05-0.50$ \\
Fulfilment $\longrightarrow$ E-s-quality & $1-6$ & $-0.05-0.45$ \\
Privacy $\longrightarrow$ E-s-quality & $1-7$ & $0.15-0.60$ \\
Systems availability $\longrightarrow$ E-s-quality & $1-6$ & $-0.10-0.25$ \\
E-s-quality $\longrightarrow$ Customer loyalty & $1-8$ & $0.20-0.80$ \\
\hline
\end{tabular}

$\mathrm{VIF}$, variance inflation factor.

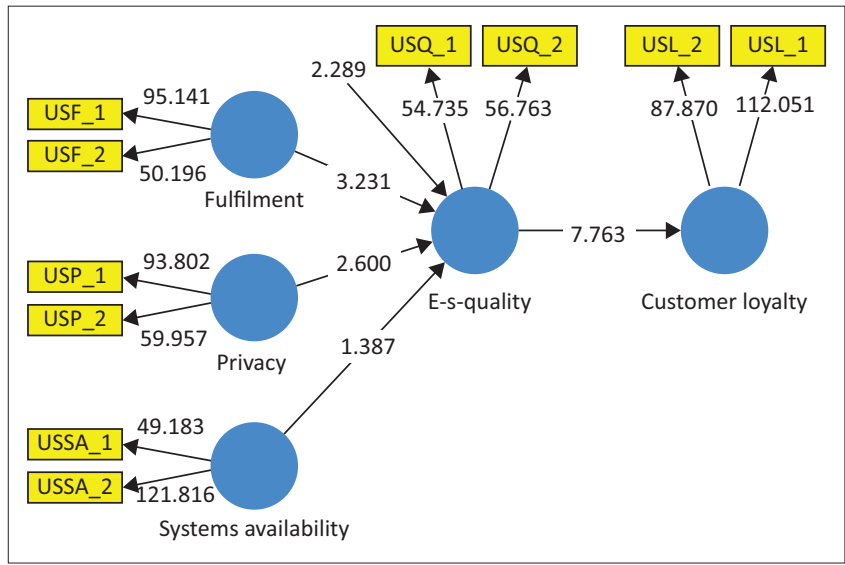

FIGURE 4: Partial least squares structural equation modelling path model for Unstructured Supplementary Service Data banking. 
Provided below is a discussion of the proposed model for MB apps.

\section{Model for mobile banking application}

The PLS-SEM model in Figure 5 displays several significant relationships. It indicates that privacy (MBP) has the strongest relationship $(t=4.889)$, followed by efficiency (MBE) $(t=3.192)$ and fulfilment (MBF) $(t=2.440)$. There is also a strong relationship between the moderator variable overall SQ (MBQ) and customer loyalty (MBL) $(t=5.532)$. As indicated by the model, it suggests that the efficiency of the MB app has a significantly positive relationship with the overall SQ of the MB app $(t=3.192)$, thereby confirming hypothesis $\mathrm{H}^{1 \mathrm{~b}}$.

Fulfilment of the MB app and overall SQ of the MB app also confirmed that hypothesis $\mathrm{H}^{2 b}$ has a strong, significantly positive relationship $(t=2.440)$. Furthermore, the model proves a desirable, significantly positive relationship between MB app privacy and MB app overall SQ $(t=4.889)$. The results therefore support $\mathrm{H}^{3 \mathrm{~b}}$. The smart PLS model further displays that there is a significant positive relationship between $\mathrm{MB}$ app overall SQ and MB app customer loyalty. The findings thus endorse $\mathrm{H}^{5 b}$. The findings, however, demonstrate that there is no statistically significant relationship between the independent variable systems availability of the MB app and the overall SQ of the MB app $(t=1.423)$. This implies that no support was found for hypothesis $\mathrm{H}^{4 \mathrm{~b}}$. Therefore, the existing discoveries validate and support $\mathrm{H}^{4 \mathrm{~b} 0}$.

\section{Multicollinearity diagnostics analysis}

The multicollinearity was analysed through variance inflation factor (VIF), which is directed at measuring the impact of collinearity among regressed variables. The analysis of multicollinearity diagnostics for efficiency and e-s-quality displayed a VIF value range of $1-5$ as well as a VIF path coefficient ranging between 0.05 and 0.50 . Furthermore, fulfilment and e-s-quality showed a VIF value ranging between 1 and 6 supported by a corresponding path coefficient ranging between -0.05 and 0.45 . The path coefficients for fulfilment and e-s-quality presented lower values, compared

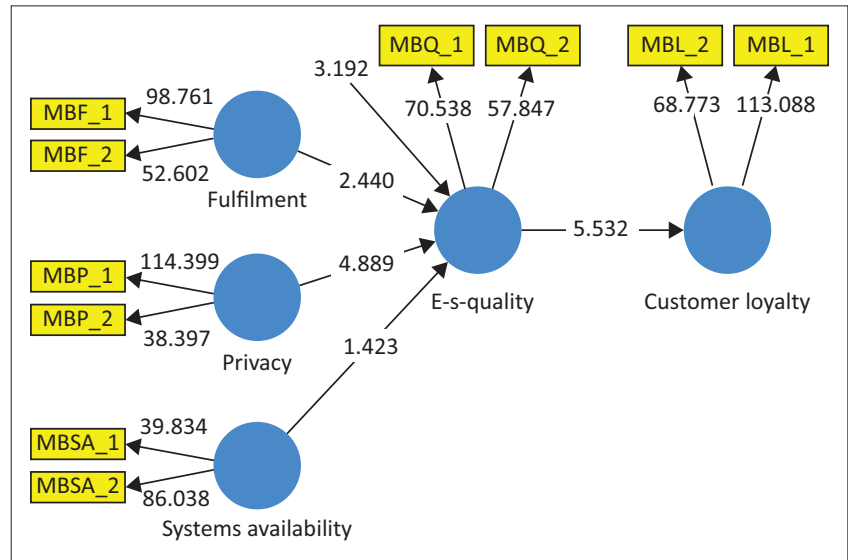

FIGURE 5: Partial least squares path model for mobile banking application. to the rest of the variables. Privacy and e-s-quality indicated a VIF path coefficient range between 0.15 and 0.60 , systems availability range was between -0.10 and 0.25 and lastly e-squality and customer loyalty also displayed a range between 0.20 and 0.80 .

\section{Discussion of secondary objectives and hypotheses}

\section{To compare the efficiency of Unstructured Supplementary Service Data banking and mobile phone banking applications concerning perceived overall service quality}

The $t$-statistics value shown in Table 6 for USSD efficiency (USE) and overall SQ (USQ) was higher than the minimum recommended $t$-value $(t=2.289)$. The findings proved that a statistically positive correlation exists between USSD efficiency (USE) and overall SQ (USQ). The suggested association between USSD efficiency (USE) and overall SQ (USQ) was therefore supported. Previous studies (Kim 2015; Kim \& Nitecki 2014; Parasuraman et al. 2005; Zeithaml, Parasuraman \& Malhotra 2002) also confirm these findings. As suggested by Kim (2015), the efficiency of USSD banking plays a critical role in the provision of overall SQ and therefore also on customer retention (Kim 2015; Kim \& Nitecki 2014; Parasuraman et al. 2005).

Comparatively, the efficiency construct was also adapted to reflect the degree to which the $\mathrm{MB}$ app platform allows ease of use when browsing or performing a transaction. The results from the PLS-SEM model $(t=3.192)$, multiple regression $(p=0.012)$ and Pearson correlation $(p=0.000)$ all proved that there is a significantly positive relationship between $\mathrm{MB}$ app efficiency and overall SQ of the MB app.

Concerning the discussion above, the higher $t$-values show that the efficiency of the MB app is more important to customers, compared to that of USSD banking. The findings indicate that customers are more concerned with how easy and efficient the MB app interface is to use. It suggests that

TABLE 6: Hypotheses Summary from partial least squares structural equation modelling path modelling result.

\begin{tabular}{|c|c|c|c|}
\hline Effective relation & $T$-statistics & Hypotheses & Significant \\
\hline \multicolumn{4}{|l|}{ Hypotheses results for MB apps } \\
\hline Efficiency E-s-quality & 3.192 & $\mathrm{H}^{1 \mathrm{~b}}-\mathrm{Accept}$ & Yes \\
\hline Fulfilment E-s-quality & 2.440 & $\mathrm{H}^{2 b}-$ Accept & Yes \\
\hline Privacy E-s-quality & 4.889 & $\mathrm{H}^{3 \mathrm{~b}}-\mathrm{Accept}$ & Yes \\
\hline Systems availability E-s-quality & 1.423 & $\mathrm{H}^{4 b}-\mathrm{Do}$ not accept & No \\
\hline E-s-quality Customer loyalty & 5.532 & $\mathrm{H}^{5 b}-\mathrm{Accept}$ & Yes \\
\hline \multicolumn{4}{|c|}{ Hypotheses results for USSD banking } \\
\hline Efficiency E-s-quality & 2.289 & $\mathrm{H}^{1 \mathrm{a}}-\mathrm{Accept}$ & Yes \\
\hline Fulfilment E-s-quality & 3.321 & $\mathrm{H}^{2 \mathrm{a}}$ - Accept & Yes \\
\hline Privacy E-s-quality & 2.600 & $\mathrm{H}^{3 \mathrm{a}}-\mathrm{Accept}$ & Yes \\
\hline Systems availability E-s-quality & 1.387 & $\mathrm{H}^{4 \mathrm{a}}-\mathrm{Do}$ not accept & No \\
\hline E-s-quality Customer loyalty & 7.763 & $\mathrm{H}^{5 \mathrm{a}}-\mathrm{Accept}$ & Yes \\
\hline
\end{tabular}

MB, mobile banking; USSD, Unstructured Supplementary Service Data. 
customers expect to be able to browse and complete the transaction quickly and without hassles when on the MB app platform. It is possible that consumers are used to the limited services that USSD banking offers and therefore do not expect these to have the same functionality as the MB app.

Therefore, banks should focus on improving efficiency specifically of the MB apps and should make available simple features and means of getting access to the application. Customers might resent using either of these mobile technology options if they possess challenging or complex interfaces, but their expectations of the MB app are higher than those for the USSD banking technology. The period that a customer has to wait until they can access the application is also significant. Continuous upgrading of the app and support systems facilitating efficiency should be a bank's priority. The language on the MB app should be made very simple and clear, with fewer steps needed to complete the transaction.

\section{To compare the fulfilment of Unstructured Supplementary Service Data banking and mobile phone banking applications concerning perceived overall service quality}

A $t$-statistical value of 3.231 was found when testing for a relationship between USSD fulfilment (USF) and overall SQ (USQ). This is a sign of a significant positive relationship and shows that the hypotheses, as mentioned above, were supported. These results are similar to those of Blut et al. (2015), Parasuraman et al. (2005) and Zeithaml et al. (2002) where a significant positive relationship was found. Although the scale from which the construct was adapted needed some work in the factor analysis process (Kim 2015), the significant relationship showed that this was not a problem. The literature available on Internet banking and other banking disciplines indicates that fulfilment plays a central role in overall SQ.

Fulfilment of MB apps and overall SQ displayed a PLS-SEM path $(t=2.440)$, which revealed a significantly positive relationship allied to the Pearson correlation analysis $(p=0.000)$. However, the multiple regression analysis disclosed somewhat contradicting results. It presented a positively non-significant value far above the maximum $p$-value $(p=0.195)$. The reason for this contradiction is not apparent. Basing the final judgement on the PLS-SEM model and Pearson correlation coefficients, hypothesis $2^{\mathrm{b}}$ was supported.

Previous studies conducted in different contexts have also verified the relationship between fulfilment and overall SQ (Parasuraman et al. 2005; Paschaloudis \& Tsourela 2014). In relation to the suggestion confirmed by both results from this study and literature, it can be concluded that fulfilment of $\mathrm{MB}$ app (MBF) and overall SQ of MB app (MBQ) are significantly positively linked.

\section{To compare the privacy of Unstructured Supplementary Service Data banking and mobile phone banking applications concerning perceived overall service quality}

As with the other variables discussed above, privacy (USP) and overall SQ (USQ) displayed similar patterns that were also found by Kim (2015), Kim and Kang (2012), and Paschaloudis and Tsourela (2014). The construct showed a strong positive $t$-statistics value of 2.600. Although the study by Kim and Kang (2012) used trust and security instead of privacy, the results confirm that privacy plays a critical role in the usage of mobile phones for banking. In an enquiry piloted by Wahab et al. (2011), it was confirmed that privacy is critical to customer retention of MB services.

With the increase in the use of mobile technology as well as mobile hacking, privacy has become one of the customers' primary concerns when using electronic devices (Subsorn \& Limwiriyakul 2012; Wahab et al. 2011). In the study concerning the MB app privacy relationship to overall SQ, the analysis showed a significant relationship. The PLS-SEM path model $(t=4.889)$, multiple regression $(p=0.000)$ and Pearson correlation $(p=0.000)$ all confirmed a significantly positive relationship between MB app privacy and overall SQ. The findings confirm the conceptual relationship suggested in the literature (Kim 2015; Parasuraman et al. 2005; Subsorn \& Limwiriyakul 2012; Paschaloudis \& Tsourela 2014; Wahab et al. 2011). Following the discussion presented above, it is clear that MB app privacy affects the overall SQ of MB apps. Therefore, hypothesis $3^{\mathrm{b}}$ is supported.

From the hypotheses findings, it can be noted that privacy of MB app (4.889) outweighs that of USSD banking (2.600). Privacy plays a critical role in MB. Banks and practitioners similarly need to consider innovative means of guaranteeing the safety of customers' information, passwords and fraudulent activities on their MB apps and USSD banking sites. The use of passwords, although convenient when logging into a bank account, can easily be hacked. Apart from using fingerprints and passwords, banks can further include other biometrics such as voice recognition access controls and eye scanners as passwords.

\section{To compare the system availability of Unstructured Supplementary Service Data banking and mobile phone banking applications concerning perceived overall service quality}

The results indicated that no significance was found between systems availability (USSA) and overall SQ (USQ). The model indicated a path showing $1.387 t$-statistics value, which was below the minimum required value. Therefore, the hypothesis was not supported by the findings. The value of the $t$-statistics (1.387) shows that there is little effect of systems availability (USSA) on overall SQ (USQ). The findings therefore do not support hypothesis $4^{\mathrm{a}}$, which suggested that system availability of USSD banking has a significantly positive relationship with the SQ of USSD banking. Recent studies have paid much attention to the relationship between systems 
availability (USSA) on overall SQ (USQ). This has been noticed in studies conducted by Kim (2015) and Paschaloudis and Tsourela (2014) where systems availability (USSA) and overall SQ (USQ) presented strong interrelationships.

Although the literature has indicated that there is a relationship between USSA and USQ, the current study found that no relationship exists between these two in the context of MB. This result contradicts the original E-S-QUAL model, where Parasuraman et al. (2005) suggested that there is an agreement between systems availability (USSA) on overall SQ (USQ).

Similarly, systems availability of MB app was also found to have no significant relationship with the overall SQ of the MB app. The results from the PLS-SEM path model presented a non-significant $t$-statistics value $(t=1.423)$. Although the PLS-SEM path model was not significant, the Pearson correlation indicated a significant relationship $(p=0.000)$ as well as multiple regression analysis.

Systems availability of MB proved not to be significant for both USSD banking and MB app. Technical interruptions, such as interfaces, that freeze and delay executed transactions can reduce customer loyalty as well as dependence on MB. Helpdesk staff should be available to deal with all technical problems as this could help improve service delivery. Competent software engineers should be available to deal with any problems related to banking software as delays caused by system availability might lead to loss of repeat customers. Parasuraman et al. (2005), however, clarified that banks have no control over the performance of this dimension and devices used at the customer's end (Internet connection and mobile phone). Therefore, systems availability is the customers' responsibility.

\section{To compare the effect of overall service quality of Unstructured Supplementary Service Data banking versus mobile phone banking applications in relation to customer loyalty}

Overall, SQ was found to have a significantly positive interrelationship with customer loyalty. Parallel to the PLS-SEM model $t$-statistics, the $p$-value from the multiple regression and correlation analyses was significant. The size of the $t$-statistics (7.763) exhibited that there is a relatively strong significant positive relationship between overall SQ of USSD and customer loyalty of USSD. This substantiates hypothesis $5^{\text {a }}$, specifically that overall e-SQ of USSD banking has a significantly positive relationship with customer loyalty.

Studies have indicated that the better the perceived overall SQ and satisfaction of customers are, the higher the possibility that the customers will be retained (Kim 2015; Meyer 2015; Ojo 2010; Rauyruen \& Miller 2006; Shanka 2012; Wahab et al. 2011; Yu 2009; Zehir et al. 2014). The results therefore prove that customer loyalty can be initiated through overall SQ among the study population. Having discussed hypotheses on USSD banking, the discussion on the MB app follows.
The provision of overall SQ has previously been confirmed to have a relationship with customer loyalty also regarded as customer retention in other studies (Aldas-Manzano et al. 2011; Parasuraman et al. 2005; Paschaloudis \& Tsourela 2014; Yang \& Tsai 2007; Zeithaml et al. 1996). The current study reported similar results as the studies presented in the literature. The findings indicated that there is a significantly positive relationship between overall SQ and customer loyalty.

Surprisingly, the Pearson correlation and PLS-SEM model all confirmed significant relationships, while the multiple regression showed contradicting results. The PLS-SEM path model displayed a $5.532 t$-statistics value, while the Pearson correlation also showed a coefficient value of $0.501(p=0.000)$. Referring to the findings above, support is drawn for hypothesis $5^{\mathrm{b}}$. Following this section will be a comparison of the results between MB app and USSD banking.

Unstructured Supplementary Service Data banking proved to have more influence on customer loyalty. Practitioners should consider investing more in the development and innovation of USSD as it may encourage customer retention. The ability to use the service by registering with the bank without having to download an application might be the reason why most customers prefer USSD banking. To improve market share, banks should engage in educating customers on MB apps and USSD banking. Therefore, banks need to work towards improving fulfilment, privacy and efficiency as these are critical to overall SQ as well as customer loyalty.

\section{Conclusions and recommendations}

The study illustrated that fulfilment, privacy and efficiency are the most critical facets of USSD banking and MB app. Of the four E-S-QUAL measurements tested, these three facets exhibited the most substantial influence on both overall SQ and customer loyalty. Therefore, banks need to place additional prominence on the USSD banking and MB apps features relating to these three dimensions. It is noteworthy that efficiency features that deal with the interface of USSD and $\mathrm{MB}$ app include simplicity and ease of access.

Privacy was also found to be a critical facet when comparing the four E-S-QUAL dimensions tested by multiple regression, Pearson correlation and the PLS-SEM model. Even though Wolfinbarger and Gilly (2003) argued that privacy might not be fundamental, they also debated that the experience of the customer with technology may alleviate concerns about information security and privacy issues. Previous studies (Parasuraman et al. 2005; Wahab et al. 2011) presented sufficient evidence to support the current study's findings that privacy does affect overall SQ and customer loyalty. Therefore, banks should continue to reassure customers of their privacy when making use of MB apps and USSD banking sites. Furthermore, biometric features, such as eye, facial and voice recognition, fingerprints and complex passwords other than the standard 'four-digit pin' can be used to improve the security of MB apps and USSD banking. The one-time password verification code could also be utilised to verify the login. 
The systems availability aspect of USSD banking and the MB app is not an essential contributor to overall SQ or customer loyalty. As indicated by Parasuraman et al. (2005), features that comprise system availability suggest that banks do not have control over the performance of this dimension and devices used at the customer's end (Internet connection and mobile phone). Banks should therefore dedicate their resources to the other aspects of SQ that positively influence customer loyalty.

The findings suggested that customer loyalty (USL) and overall SQ (USQ) of USSD banking exhibited a stronger relationship, compared to the influence between customer loyalty (MBL) and overall SQ (MBQ) of MB app. These findings imply that banks might need to spend more resources on improving the overall $\mathrm{SQ}$ of the $\mathrm{MB}$ app to improve customer retention. The need for the Internet when using the banking application might be the reason why customer retention on the MB app is low. It seems that customers cannot afford the high cost of being connected to their banks through the banking application. Therefore, to improve customer retention of $\mathrm{MB}$ app, banks should consider providing free access Wi-Fi hotspots to cater for customers who might need to connect to the bank through the banking application. Furthermore, banks should further consider allowing free MB app access similar to the same medium used through USSD banking. This could aid in improving both customer retention as well as the number of transactions executed every year on the MB app.

Digital and technological innovation is increasingly at the forefront of economic growth and success. This is the time for banks to leverage the growth in MB platforms for increasing their market share as well as reaching out to the South African non-banked portion of the population. It is not enough for banks to provide MB platforms, but there also needs to be inclusion of better banking platforms with fourth industrial revolutionary features such as face recognition software, eye scanning and branchless banking. However, marketing campaigns should not only focus on the technology but also on the factors that are critical to overall SQ and customer loyalty, such as customer fulfilment, efficiency and privacy issues of the technology, which are fundamental to USSD or cell phone banking and $\mathrm{MB}$ application. These findings provide beneficial insights to both practitioners and academia with regard to overall SQ and customer loyalty in MB. While it is accepted that several factors other than e-S-QUAL dimensions may influence customer loyalty, this study provides some guidelines towards the development of an integrated framework of factors influencing customer loyalty towards MB.

\section{Limitations and future research}

One of the limitations of the study was the sample size of 218 respondents and the fact that only one university was included in the study, which can limit the generalisability of the research. The study also made use of a convenience, rather than a systematic, sampling technique, which may have biased the results. The scales used in the study were adapted from studies conducted internationally, which could also be a limitation to the study as there may be important factors that were not included in the South African context. Lastly, the research made use of a quantitative research approach, which meant that conclusions were made based on numerical data. If the research had followed both a qualitative and quantitative approach, the findings could be more in-depth and provide a richer overview of the problem.

As the research study followed a quantitative research approach, future research should follow a qualitative research approach to gain a more in-depth insight into the problem. Future research should include students from other rural and urban universities to provide a comparative sample. Lastly, the scales should be tested in the South African context to develop specific scales that are relevant to the country.

\section{Acknowledgements}

I mean we mainly want to thank the University of Fort Hare and the National Research Foundation for the financial support tendered for this research.

\section{Competing interests}

The authors have declared that no competing interest exist.

\section{Authors' contributions}

D.C. collected the data and wrote the initial draft of the article, K.V. and M.F. supervised and refined the first draft of the article and L.C. finalised the second draft of the article.

\section{Ethical considerations}

Ethical approval to conduct the study was obtained from the University of Fort Hare, REC-270710-028-ra Level 01 (Certificate ref. no. VIL 121SCHO01) on 05 August 2016.

\section{Funding Information}

The research study was partly funded by Dr Prof Viljoen's Seed Grant Account (C135) from the University of Fort Hare and partly by Thuthuka Grant National Research Foundation (NRF) (used to pay statistician and language editing), with grant number TTK150713125504.

\section{Data availability statement}

Data sharing is not applicable to this article as no new data were created or analysed in this study.

\section{Disclaimer}

The views and opinions expressed in this article are those of the authors and do not necessarily reflect the official policy or position of any affiliated agency of the authors. 


\section{References}

Adewoye, J., 2013, 'Impact of mobile banking on service delivery in the Nigerian commercial banks', International Review of Management and Business Research 2(2), 333-344.

Agbor, J.M., 2011, The relationship between customer satisfaction and service quality: A study of three service sectors in Umeå, Umeå.

Aldas-Manzano, J., Ruiz-Mafe, C., Sanz-Blas, S. \& Lassala-Navarré, C., 2011, 'Internet banking loyalty: Evaluating the role of trust, satisfaction, perceived risk and frequency of use', The Service Industries Journal 31(7), 1165-1190. https://doi. frequency of use', The Service Ind
org/10.1080/02642060903433997

Ariff, M.S.M., Yun, L.O., Zakuan, N. \& Ismail, K., 2013, 'The impacts of service quality and customer satisfaction on customer loyalty in internet banking', In Procedia - Socia and BehavioralSciences 81, 469-473. https://doi.org/10.1016/j.sbspro.2013.06.462

Axis Bank, 2016, Types of mobile banking, itsallaboutmoney.com, viewed 16 September 2016, from http://www.itsallaboutmoney.com/convenience-banking/ mobile-banking/types-of-mobile-banking/

Ayo, C.K., Oni, A.A., Adewoye, O.J. \& Eweoya, I.O., 2016, 'E-banking users' behaviour: E-service quality, attitude, and customer satisfaction', International Journal of Bank Marketing 34(3), 347-367. https://doi.org/10.1108/IJBM-12-2014-0175

BASA, 2014, South African Banking Sector Overview, Banking Association South Africa (BASA), Johannesburg.

Beard, R., 2014, Why customer satisfaction is important (6 reasons), viewed 12 July 2016, from http://blog.clientheartbeat.com/why-customer-satisfaction-isimportant/

Blut, M., Chowdhry, N., Mittal, V. \& Brock, C., 2015, 'E-service quality: A meta-analytic review', Journal of Retailing 91(4), 679-700. https://doi.org/10.1016/j. jretai.2015.05.004

Boshoff, C. (ed.), 2014, Services marketing: a contemporary approach, 2nd edn., Juta \& Company Ltd, Cape Town.

Burger, S., 2010, Mobile banking for South Africa?, viewed 22 July 2016, from http:// www.engineeringnews.co.za/article/mobile-banking-for-southafrica-2010-09-24/rep_id:4136

Dobush, G., 2015, How mobile phones are changing the developing world-Consume Technology Association, viewed 04 April 2016, from http://www.cta.tech/Blog/ Articles/2015/July/How-Mobile-Phones-Are-Changing-the-Developing-Worl.aspx

Duff, S., 2014, The latest statistics on South African Internet penetration, Web Africa Blog, viewed 03 May 2016, from https://www.webafrica.co.za/blog/general/ latest-statistics-south-african-internet-penetration/

EffectiveMeasure, 2014, South Africa mobile report: A survey of desktop user's attitudes and uses of mobile phones, viewed 28 May 2016, from http://www. effectivemeasure.com

Erspective, L.O.P. \& Lusch, R.F., 2015, 'Service innovation: A Service-dominant-logic perspective', MIS Quarterly 39(1), 155-175.

Fenu, G. \& Pau, P.L., 2015, 'An analysis of features and tendencies in mobile banking apps', Procedia Computer Science 56(1), 26-33. https://doi.org/10.1016/j. procs.2015.07.177

Grönroos, C., 1984, 'A service quality model and its marketing implications', European Journal of Marketing 18(4), 36-44.

Halliburton, P.C. \& Poenaru, A., 2010, 'The role of trust in consumer relationships', International Journal of Research in Marketing 20(1), 0-16.

Hanafizadeh, P., Behboudi, M., Abedini, K.A. \& Jalilvand, S.T.M., 2014, 'Mobile-banking adoption by Iranian bank clients', Telematics and Informatics 31(1), 62-78. https://doi.org/10.1016/j.tele.2012.11.001

Henseler, J., Ringle, C.M. \& Sarstedt, M., 2014, 'A new criterion for assessing discriminant validity in variance-based structural equation modelling', Journal of the Academy of Marketing Science 43(1), 115-135. https://doi.org/10.1007/ the Academy of Mark

Henseler, J. \& Sarstedt, M., 2013, 'Goodness-of-fit indices for partial least squares path modelling', Computational Statistics 28(2), 565-580. https://doi. path modelling', Computation
org/10.1007/s00180-012-0317-1

Hodgkinson, D., 2015, Mobile banking 2015, KPMG, viewed 21 June 2016, from http://cs.stanford.edu/people/eroberts/cs181/projects/2010-11/SmartPhones/ pt4.html

Honigman, B., 2014, How to decide between a responsive website or a native mobile app, viewed 08 February 2014, from http://thenextweb.com/dd/2014/02/08/ decide-responsive-website-native-mobile-app/

Ivatury, G. \& Pickens, M., 2006, Mobile phone banking and low-income customers: Evidence from South Africa, Consultative Group to Assist the Poor, Washington, DC.

Kim, H.M., 2015, The applicability of E-S-QUAL for assessing the service quality, Drexel University, Philadelphia.

Kim, H.M. \& Nitecki, D.A., 2014, 'A proposed scale for measuring the quality of social media services: An E-S-QUAL approach', Proceedings of the American Society for Information Science and Technology 51(1), 1-4. https://doi.org/10.1002/ meet.2014.14505101104

Kim, J., Jin, B. \& Swinney, J.L., 2009, 'The role of etail quality, e-satisfaction and e-trust in online loyalty development process', Journal of Retailing and Consumer Services 16(4), 239-247. https://doi.org/10.1016/j.jretconser.2008.11.019

Kim, J.B. \& Kang, S., 2012, 'A study on the factors affecting the intention to use smartphone banking: The differences between the transactions of account check and account transfer', International Journal of Multimedia and Ubiquitous Engineering 7(3), 87-96.
Kim, M., Kim, J.-H. \& Lennon, S.J., 2006, 'Online service attributes available on apparel retail web sites: An E-S-QUAL approach', Managing Service Quality:An retail web sites: An E-S-QUAL approach', Managing Service Quality:An
International Journal 16(1), 51-77. https://doi.org/10.1108/09604520610639964

Lovelock, C.H. \& Wirtz, J., 2011, Services marketing - people, technology, strategy, 7th edn., pp. 26-50, Pearson Education, Edinburgh.

Lu, C., Geng, W. \& Wang, I., 2015. 'The role of self-service mobile technologies in the creation of customer travel experiences', Technology Innovation Management Review 5(2), 24-32.

Masocha, R., Chiliya, N. \& Zindiye, S., 2011, 'E-banking adoption by customers in the rural milieus of South Africa: A case of Alice, Eastern Cape, South Africa', African Journal of Business Management 5(5), 1857-1863.

Matthew, D., 2013, Factors that impact consumer adoption of mobile banking within the m-commerce domain, The University of the Witwatersrand, Johannesburg.

Meyer, J., 2015, The future of mobile banking in South Africa, Fin24tech, viewed 16 March 2016, from http://www.fin24.com/Tech/Opinion/The-future-of-mobilebanking-in-South-Africa-20150211

Nyeko, J.S., Moya, M., Kabaale, E. \& Odongo, J., 2014, 'Factors influencing the short message service (SMS) mobile banking adoption: A users' perspective in the West Nile region in Uganda', European Journal of Business and ManagementOnline 6(5), 2222-2839.

Ojo, O., 2010, 'The relationship between service quality and customer satisfaction in the telecommunication industry: Evidence from Nigeria', Broad Research in Accounting, Negotiation, and Distribution 1(1), 88-100.

Ondiege, P., 2010, 'Mobile banking in Africa: Taking the bank to the people', Africa Economic Brief 1(8), 1-15.

Oppong, P., Adjei, H. \& Poku, K.P., 2014, 'The role of information technology in building customer loyalty in banking: A case study of Agricultural Development Bank Ltd., Sunyani', British Journal of Marketing Studies 2(4), 9-29.

Parasuraman, A., Zeithaml, V.A. \& Berry, L.L., 1985, 'A conceptual model of service quality and its implications for future research', Journal of Marketing 49(4), 41-50. https://doi.org/10.1177/002224298504900403

Parasuraman, A., Zeithaml, V.A. \& Malhotra, A., 2005, 'E-S-QUAL: A multiple-item scale for assessing electronic service quality', Journal of Service Research 7(3), 213-233. https://doi.org/10.1177/1094670504271156

Paschaloudis, D. \& Tsourela, M., 2014, 'Using E-S-QUAL to measure internet service quality of e-banking web sites in Greece', Journal of Internet Banking and Commerce 19(2), 1-17.

Rafiq, M., Lu, X. \& Fulford, H., 2012, 'Measuring Internet retail service quality using E-S-QUAL', Journal of Marketing Management 28(9-10), 1159-1173. https://doi. E-S-QUAL', Journal of Marketing Man
org/10.1080/0267257X.2011.621441

Rauyruen, P. \& Miller, K.E., 2006, 'Relationship quality as a predictor of B2B customer loyalty', Journal of Business Research 60(1), 21-31. https://doi.org/10.1016/j. jbusres.2005.11.006

Santouridis, I. \& Kyritsi, M., 2014, 'Investigating the determinants of internet banking adoption in Greece', Procedia Economics and Finance 9, 501-510. https://doi. org/10.1016/S2212-5671(14)00051-3

Shaikh, A.A. \& Karjaluoto, H., 2014, 'Mobile banking adoption: A literature review', Telematics and Informatics 32(1), 129-142. https://doi.org/10.1016/j.tele.2014.05.003

Shanka, M.S., 2012, 'Bank service quality, customer satisfaction and loyalty in Ethiopian banking sector', Journal of Business Administration and Management Sciences Research 1(1), 1-9.

Singh, A.B., 2012, 'Mobile banking based money order for India Post: Feasible model and assessing demand potential', Procedia - Social and Behavioral Sciences 37, and assessing demand potential', Procedia- Social and B

Subsorn, P. \& Limwiriyakul, S., 2012, 'A comparative analysis of internet banking security in Thailand: A customer perspective', Procedia Engineering 32, 260-272. https://doi.org/10.1016/j.proeng.2012.01.1266

Tenenhaus, M., Amato, S. \& Vinzi, V.E., 2014, 'A global Goodness-of-Fit index for PLS structural equation modelling', in Proceedings of the XLII SIS Scientific Meeting, CLEUP, Padova, June 01, 2012, pp. 739-742.

Van Velden, L., Roopnarain, R., Kana, H. \& Nitish, M., 2015, Resilent through challenging times. Major banks analysis - South Africa, Price Waterhouse Cooper, Johannesburg.

Wahab, S., Zahari, A.S, Momani, K.A. \& Nor, N.A., 2011, 'The influence of perceived privacy on customer loyalty in mobile phone services: An empirical research in Jordan', International Journal of Computer Science 8(2), 45-52.

Wolfinbarger, M. \& Gilly, M.C., 2003, 'eTailQ: Dimensionalizing, measuring and predicting retail quality', Journal of Retailing 79(3), 183-198. https://doi. predicting retail quality', Journal of
org/10.1016/S0022-4359(03)00034-4

Yang, H. \& Tsai, F.-S., 2007, ‘General E-S-QUAL scales applied to websites satisfaction and loyalty model', Communications of the IIMA 7(2), 115-126.

Yu, S., 2009, Factors influencing the use of mobile banking: The case of SMS-based mobile banking, Auckland University of Technology, Auckland.

Zehir, C., Sehitoglu, Y., Narcikara, E. \& Zehir, S., 2014, 'E-S-quality, perceived value and loyalty intentions relationships in internet retailers', Procedia - Social and Behavioral Sciences 37, 1071-1079. https://doi.org/10.1016/j.sbspro.2014.09.120

Zeithaml, V.A., Berry, L.L. \& Parasuraman, A., 1996, 'The behavioural consequences of service quality', Journal of Marketing 60(2), 31-46. https://doi.org/10.2307/1251929

Zeithaml, V.A., Parasuraman, A. \& Malhotra, A., 2002, 'Service quality delivery through web sites: A critical review of extant knowledge', Journal of the Academy of Marketing Science 30(4), 362-375. https://doi.org/10.1177/009207002236911

Zeithaml, V.A., Bitner, M.J. \& Gremler, D.D., 2013, Services marketing, 6th edn., McGraw-Hill Education, Berkshire. 